\title{
Osądy wartościujące w naukach społecznych i w filozofii politycznej - dyskusja stanowiska Maxa Webera"
}

Koncepcja sądów wartościujących Maxa Webera nadal może stanowić punkt wyjścia do dzisiejszego namysłu nad wieloma istotnymi pytaniami. Weber dwukrotnie podejmował ów problem - raz skupiając się na kwestii neutralności socjologii i empirycznych nauk społecznych (a także filozofii społecznej), które koncentrować się miałyby na ustalaniu faktów; po raz drugi analizując rolę uczonych i standardy nauczania, gdzie również powstrzymywanie się od wartościowania (odróżnianego, za Rickertem, od odniesień do wartości) miałoby obowiązywać. Sam Weber zdawał sobie sprawę z trudności, jakie nastręcza takie stanowisko, jednak - w mej opinii - nie udało mu się ich przezwyciężyć. Najbardziej kłopotliwą przesłanką jego wywodów w tym zakresie jest głośna Weberowska teza o zasadniczej nieuzasadnialności sądów wartościujących. Leo Strauss uważał, że to stanowisko wiedzie wprost do nihilizmu. Inaczej sądził Eric Voegelin, który doszukiwał się w pewnych fragmentach prac Webera klasycznych elementów Platońskich i Arystotelesowskich. Ze swej strony wysuwam liczne wątpliwości i ze znaczną częścią wywodów Webera trudno mi się zgodzić.

Brak wyraźnych ocen, zaciemnianie własnych przeświadczeń moralnych czy metafizycznych, "przemycanie ich” w drodze jakichś ukrytych strategii perswazyjnych nie daje się pogodzić z najskromniej poj-

Autoreferat wystąpienia w PTF OG, 27.05.2013. W postaci artykułu rozszerzony jego wariant ukazał się w mojej książce Makiawelizm, patologia ducha, sacrum i polityka. Eseje z filozofii politycznej (Spółdzielczy Instytut Naukowy, Sopot, 2016) - jako część rozdziału 4 pt. „Filozof w polis”, s. 253-271. 
mowanym etosem rzetelności uczonych. Tego rodzaju praktyki niosą ze sobą szereg niebezpieczeństw, uzurpacji i manipulacji. Trzeba zgodzić się ze Straussem, że Weber zrywając swe związki ze szkołą historyczną i przechodząc na pozycję nominalizmu, odrzuca zarazem pozostałości prawa naturalnego, $\mathrm{w}$ to miejsce podstawiając obraz rzeczywistości jako chaosu, nad którym miałby panować jakoś uczony, np. konstruując swe typy idealne. $Z$ drugiej strony, wedle Webera, każdy z osobna człowiek we własnym sumieniu musiałby rozstrzygać o sensie czy bezsensie świata, formułując zarazem swe osobiste osądy wartościujące. Wreszcie obraz nauki zachowującej swą ważność w odniesieniu do odkrywanych (raz na zawsze) faktów, nauki „takiej samej dla Europejczyka i dla Chińczyka", nauki niezależnej od jakiegokolwiek światopoglądu i od sądów wartościujących dopełnia miary dość desperackich rozstrzygnięć wielkiego niemieckiego uczonego. Uważam je za desperackie i zarazem za fałszywe. Prawdopodobnie Weber sam nie był bezkrytyczny względem swoich osobistych osądów wartościujących i wypowiadał wiele opinii sprzecznych lub przynajmniej pozostających w poważnym napięciu ${ }^{1}$.

Osobliwość stanowiska Webera Strauss streszcza następująco: „wartości ostateczne są tak samo wieczne jak zasady logiki"; u Webera mamy więc szczególne pojęcie wartości ponadczasowych - każdemu jakoś odsłaniających się w jego sumieniu lub też powstających w indywidualnej duszy obcującej z demonami i konfrontowanej z własnym przeznaczeniem. To pojęcie wartości „,stanowi u niego podstawę odrzucenia praw naturalnego" (Prawo naturalne w świetle historii, PAX, Warszawa 1969, s. 43).

Weber, jak wiadomo - ostro odgraniczając fakty od wartości - związał się też z pewną odmianą pozytywizmu. Upierając się przy tezie, że z ustalenia faktów niczego nie sposób wnioskować o wartościach i na odwrót, doszedł do jakiegoś post-kantowskiego wyobrażenia ludzkiej autonomii w dziedzinie osądów wartościujących².

$* * *$

W mej ocenie, istnieją zasadnicze trudności w rozdzielaniu (Rickertowskich) odniesień do wartości (tj. współczynnika humanistycznego, który ma zawsze aspekt aksjologiczny) od „praktycznego wartościowania”;

1 Np. jego analiza pojęcia prawa naturalnego jest na tyle ambiwalentna, że Voegelin wziął ją za oznakę pewnego przychylenia do klasycznej koncepcji prawa naturalnego, moim zdaniem - raczej nietrafnie.

2 Strauss stanowczo powiada, że "teza Webera [o nieuzasadnialności osądów wartościujących] z konieczności prowadzi do nihilizmu lub do poglądu, że trybunał rozumu ludzkiego musi uznać każdy wybór - nawet najgorszy, najpodlejszy czy najbardziej szalony - Zarównie słuszny jak jakikolwiek inny" (s. 45). 
owszem socjolog (jak i filozof społeczny) powinien starannie rozgraniczać pomiędzy osądem własnym i cudzym, pomiędzy odniesieniem do wartości, jakie odnajduje u badanych przez siebie ludzkich podmiotów, społeczeństw, grup, a własnymi moralnymi przeświadczeniami. Jednakże, gdy czynimy zadość temu wymaganiu, nie udaje się $\mathrm{w}$ ten sposób, prawdę mówiąc, konsekwentnie zawiesić naszych własnych (przynajmniej) cząstkowych osądów czy odczuć wartości, gdyż ich współ-dokonywania stanowią nieusuwalną część samych tylko aktów poznawczych - rozumienia zjawisk ludzkich czy społecznych. Zawieszenie osądu moralnego zbrodni dokonywanych w obozach zagłady sprawiałoby, że nie bylibyśmy w stanie sensownie opisać tego, co działo się pod okupacją niemiecka, w krajach podbijanych czy w czasach rządów nazistowskich także w Niemczech.

Uczeni pozostają ludźmi, członkami ludzkich wspólnot, społeczeństw, cywilizacji czy - wreszcie najszerszego zbiorowiska - ludzkości czy w końcu najobszerniejszej - zbiorowości osób żyjących i umarłych. Prócz obowiązku poszukiwania prawdy, ciąży na nich także troska o dobro wspólne ${ }^{3}$. Gdy są w stanie zapobiegać złu lub chociaż przed nim ostrzegać, to powinni to czynić. Gdy mogą wystąpić w roli diagnostyków patologii społecznych czy duchowych, powinni to czynić z najwyższą osiągalną odpowiedzialnością. Czy oznacza to, że diagnozy swe i ostrzeżenia mają wypowiadać (wyłącznie) poza salą wykładową? Nie sądzę! Choć podzielam przekonanie Webera o koniecznej powściągliwości wykładających i nie narzucaniu młodzieży swych ostatecznych, najwyższych osobistych (a tym bardziej jakichś polityczno-partyjnych) przekonań i osądów ani otwarcie, ani skrycie. Lecz z drugiej strony ich zatajanie czy tłumienie wydaje się raczej wadą niż zaletą i to nie tylko ze względu na retoryczne walory wypowiedzi czy widowiskowość.

$\mathrm{O}$ wiele bardziej podstępne, a tym samym naganne, wydaje się manipulowanie językiem, tj. narzucanie jakiegoś sztucznego żargonu, w którym już zawarte są rozstrzygnięcia wartościujące, przy zachowaniu pozorów „naukowości”. Jest to możliwe już na poziomie samego tylko opisywania wyselekcjonowanych faktów czy konstruowania przesłanek teoretycznych przy badaniu tego czy innego zjawiska czy pojęcia (np. sprawiedliwości przez J. Rawlsa).

3 W „Nauce jako zawodzie i powołaniu” czytamy: „Niemożność «naukowej» argumentacji na rzecz postaw praktycznych - z wyjątkiem przypadku, gdy rozważane są środki do celu, o którym zakłada się, że jest z góry d a $\mathbf{n} \mathbf{y}$ - wypływa z daleko głębszych powodów. Postawa przeciwna jest dlatego zasadniczo bezsensowna, ponieważ w świecie toczą ze sobą nieubłaganą walkę różne porządki wartości", (Z. Krasnodębski, Weber, s. 212). Otóż ów rzekomy wyjątek 'z góry danego celu', to wszak klasyczny przypadek kategorii dobra wspólnego; rozumienie tego dobra może i jest sporne, lecz potrafimy rozgraniczać nihilistycznych heroldów negacji jego istnienia od tych, którzy zakreślają znaczenie tego dobra, pojmując je szerzej lub wężej... 
Właściwsze, moim zdaniem, jest otwarte ujawnianie własnych przekonań światopoglądowych czy też transparentne dawanie ich do zrozumienia. Wówczas odniesienia do wartości, stanowiące składową operacji poznawczo-opisowych dokonywanych przez badacza, łatwiej będzie poddawać niezależnej kontroli i łatwiej będzie je można skorygować lub sfalsyfikować.

Moje własne stanowisko na dyskutowaną kwestię neutralności aksjologicznej czy osądów wartościujących wygląda następująco: uczony filozof czy socjolog powinien rzeczywiście zachować dystans względem niektórych gorączkowych sporów np. politycznych czy światopoglądowych, lecz do zupełnego unikania wyrażania własnych osądów w ogóle nie jest zobowiązany i nawet zobowiązywany być nie powinien. Jedną rzeczą jest rezerwa względem partykularnych, interesownych, partyjnych punktów widzenia ${ }^{4}$ na aktualną rzeczywistość vs. (nie-)porządek społeczny, a inną całkowita neutralność względem dobra i zła, sprawiedliwości i niesprawiedliwości itp. Uczony może i powinien bronić wartości uniwersalnych, formułować przestrogi przed poniewieraniem dobra wspólnego, przewidywać i diagnozować niebezpieczeństwa i zagrożenia. A tego wszystkiego nie byłby w stanie czynić bez osobistego angażowania się po tej czy innej stronie sporów.

Natomiast wyróżniać go powinno, prócz rozwagi i umiaru, przemyślane uzasadnianie własnych osądów, uwiarygodnienie słów krytyki, zorientowanie na wartości długofalowe, intelektualna rzeczowość i uczciwość, cnoty intelektualne, staranie o podniesienie poziomu publicznych sporów.

Te wszystkie dezyderaty może realizować i nauczając na katedrze i poprzez publikacje $w$ odpowiednich pismach.

Podsumowując, trudno się bezwarunkowo z postulatem neutralności aksjologicznej Webera zgodzić. Zarówno akademicki wykład z etyki, filozofii religii, metafizyki, jak analizy z zakresu filozofii polityki czy teo-

4 Nie wydaje mi się, żeby sensowny miał być tym samym bezwzględny zakaz opowiadania się po tej czy innej stronie sporów partyjnych. Jeżeli jedna partia, zwłaszcza będąca u władzy, jest z punktu widzenia uczonego wyjątkowo szkodliwa, sprzeniewierza się oczywistym wartościom ponadpartykularnym, a znowuż inne polityczne ugrupowanie rozsądnie tamtą, rządzącą zwalcza, uczony może zaryzykować własną niezależność i wspierać argumentację opozycyjnej, jeśli ma do tego głębokie przekonanie i zachowuje rzeczowość argumentacji. Oczywiście nie powinien wszakże stać się uczonym dyspozycyjnym względem jakiejkolwiek partii, a zwłaszcza rządzącej. Nie można jednak spokojnie i raz na zawsze popierać opozycji jako opozycji, gdyż ta może niekiedy np. torować drogę tyranii jakiegoś wodza albo oligarchicznym rządom kliki. 
rii cywilizacji - mimo ryzyka błędów - nie muszą i nawet nie powinny unikać warunkowego formułowania osądów wartościujących. Przykładowo: prowadząc porównawcze badania nad cywilizacjami czy diagnozując stan naszej własnej cywilizacji Zachodu obecnie, nie możemy unikać odniesień do wartości, nie wolno nam zrównywać zachowań cywilizowanych od zdziczenia obyczajów, nie wolno udawać, że zbrodnia i niegodziwość, szalbierstwo i podstępność są czymś równie dobrym, co ich przeciwieństwa. Uczony, który by sobie na to pozwalał moralnie, byłby sam dzikusem i barbarzyńcą. 